established practice has not been introduced without considerable criticism and opposition, but it is probable that in a very short time it will be regarded as an eminently sensible and desirable alteration.

\section{Research at the Port Erin Biological Station}

A separate report on the work of the Port Erin Biological Station has been discontinued and a survey of the research done is now published in the "Report for 1931 (No. 40) on the Lancashire Sea-Fisheries Laboratory at the University of Liverpool and the Annual Report of the Marine Biological Station (No. 45) at Port Erin, Isle of Man', 1932, edited by the late Prof. James Johnstone and Dr. R. J. Daniel. In this report a large amount of original work is also published. This covers a wide field and deals with the abdominal musculature of Crustacea, herring investigations, hydrography and the fauna and flora of the Isle of Man. The Port Erin Station has recently (1931-32) had a new laboratory added, fully equipped for practical teaching and with about thirty work places. New engines and pumps have been installed. The plaice hatchery and lobster culture are still continued. Besides liberating lobsterlings hatched and reared in the laboratory, a number were placed singly in glass rearing jars and fed on crab, boiled and ground to a fine meal. Nearly half of the number survived and cast their shells four or five times, making eight or nine casts between the period of hatching and the end of the first year. The newly hatched young are fed on fresh plankton; after the fourth moult (lobsterling) they are fed on crushed crab, small pieces of fish being added after the fifth month. These interesting experiments are to be continued on a larger scale next year. Dr. R. $J$. Daniel has completed his comparative work on the abdominal muscles of the Malacostraca and has drawn up an elaborate phylogenetic table to express the relationships that exist between the main ventral system of musculature.

\section{A New Source of Rubber}

IN order to avoid the necessity of importing rubber from tropical countries, the Soviet Government has organised investigations of native plants likely to contain this valuable product in their latex. Amongst various plants studied, several species of Chondrilla (Compositæ) occurring mainly in the southern sandy regions, proved to be very promising and their cultivation is being carried out on an extensive scale. Green parts of the plant are cut and rubber prepared from the latex. The quantities obtained must be rather small, since only up to 2 per cent of the green mass represents rubber. Recently, however, it was found that certain insects feeding on roots of Chondrilla can be utilised for extracting rubber from the latex (Veltischev and Luppova, Priroda, No. 10, 1932). One of these is a caterpillar of a pyralid moth, Bradyrrhoa gitveolella Tr., which feeds on the roots and constructs round its body a tube formed of condensed latex and sand grains. Up to thirty and more such tubes can be found on the roots of a single plant, and the tubes contain 9-17 per cent of rubber. Another useful insect is the larva of a buprestid beetle, Sphenoptera foveola Gebl., which also feeds on roots of Chondrilla and causes a large outflow of latex solidifying round the root. These swellings contain up to 4 per cent of rubber. Neither insect produces any serious effect on the infested plant, and healthy plants can be infested artificially in order to increase their productivity. Experiments are being made to test the practical and economic side of this method of obtaining rubber.

\section{Cultivation of Green Crops}

Bulletrn No. 53 of the Ministry of Agriculture and Fisheries ("Cabbages and Related Green Crops". London: H.M. Stationery Office, Price 9d.) has recently been published. It traces the botanical origin of the various green crops, and deals in detail with the soils, rotation, manuring, harvesting and marketing most suitable for cabbages, savoys, Brussels sprouts, cauliflowers and several miscel. laneous green crops. A very interesting section deals with the saving of seed in the counties the climate of which is most suitable for this purpose. Pests and diseases are not mentioned in the present pamphlet, since they have been described very fully in other publications of the Ministry.

\section{Astrolabes and Their History}

Astrolabes are not as generally available for study in the museums of the world as their scientific importance and artistic qualities would merit, but all who may desire to become better acquainted with this instrument in its various forms are now given the opportunity. Subscribers are invited for a comprehensive work, entitled "The Astrolabes of the World", based upon the series of instruments in the Lewis Evans Collection in the Old Ashmolean Museum at Oxford, in the Seience Museum at South Kensington, and in several other public and private collections in Europe and America. The early Greek treatise on the astrolabe, by Philopon, and the Syriac treatise by Sabokt - both dating from the seventh century-will appear in English for the first time. Illustrations are given of Chaucer's astrolabe, now clearly identified by the character of the rete as depicted in MSS. and many instruments contemporary with Columbus and Drake, are figured. The subject is of fundamental importance to all students of the history of astronomy, geography and surveying, and indeed to the history of science generally, for it may truly be said that the astrolabe kept alight the torch of the scientific method of observation and of computation of results, in many countries, and through many dark ages, when larger instruments and well equipped observatories did not exist. It is hoped that the principal reference libraries may obtain copies of this monumental work, which it is proposed to issue in two quarto volumes, containing more than 600 pages and 155 plates, of which 12 are in eollotype, and 216 text figures. The price to subscribers is ten guineas. Subscription forms may be obtained from Dr. R. T. Gunther, Curator of the Lewis Evans Collection, in the Old Ashmolean, Broad Street, Oxford. 